\title{
Study on the Influence of Economic Growth Model on Current Account Balance and its Countermeasures
}

\author{
Yanhong Gong, Feng Xu \\ University of Tibet, Lhasa, Tibet 850000 , China
}

\begin{abstract}
At present, China is facing the severe international situation of the escalating Sino-US economic and trade frictions and the spread of the epidemic and is in the transition stage of the domestic economy from high-speed development to high-quality development. The development of these domestic and foreign factors has a profound impact on the change of China's current account balance. This paper expounds the current situation of current account balance changes in China, and empirically studies the impact of economic growth, industrial structure, fiscal expenditure and consumption expenditure on current account changes through VAR model. Finally, some policy suggestions are put forward, such as adjusting the target range of current account balance, establishing a current account management system adapted to the domestic and international double cycle, and improving the ability of consumption to adjust the fluctuation of current account balance.
\end{abstract}

Keywords: Economic growth model, Current account balance, The VAR model.

\section{Introduction}

In recent years, with the great changes in the international monetary structure and economic system, China's participation in the global economy has undergone profound changes. Investment and export have always been important driving forces for China's economic growth, while consumption is relatively weak, which is also the reason why China's current account has been in large surplus for a long time. On the one hand, the independence and effectiveness of China's monetary policy are facing severe challenges; on the other hand, the long-term large current account surplus keeps increasing China's foreign exchange reserves. Under China's current economic growth model, it is urgent to study the influence of different economic variables on the current account balance and how to effectively solve the risks faced by China's current account.

Uneven distribution of global resources has always been the main cause of international economic imbalance. Cheap labor and resources in China lead to China's trade surplus (Li Gege, 2016), and the international division of labor in manufacturing and financial industry also leads to global imbalance (Teng Yankai, 2017). At present, China is also facing the severe situation of Sino-US trade friction. The historical US-Japan trade friction has influenced the trade balance, especially the current account balance, through exchange rate, fiscal policy and trade opening conditions (Dong Dezhi, Jin Jiaqi, 2018). In the Sino-US trade friction, it has a linkage effect on enterprises' withdrawal from the international market and welfare loss (Wang Zeyu, 2019; Lv Yue, 2019). Gaballero et al. (2006), Gruber, Kamin (2007) and Ito (2009) all believe that the imbalance between consumption and savings leads to the imbalance of international economy. In addition, fiscal policy can play a role through various micro-mechanisms in combination with current income levels, rather than simply linking fiscal deficit to current account deficit (Zhang Yu, Li Guihua, 2018).
Fragile industrial structure (Liang Limin, 2017) and urban-rural dual structure (Hua Min, 2014) also lead to excessive current account surplus.

In this context, this paper elaborates the status quo of China's current account and focuses on the impact of economic variables such as economic growth, industrial structure, fiscal expenditure and consumption expenditure on the current account balance, so as to provide comprehensive and objective suggestions for the future development direction of China's current account.

\section{Analysis of Current Account Status in China}

\subsection{Changes in China's Current Account Balance}

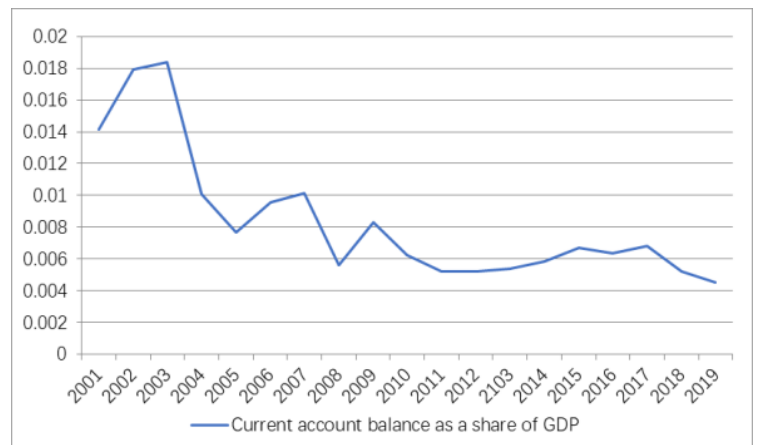

Figure 1: Depicts the change of China's current account balance and its share in GDP from 2001 to 2019.

Data source: Website of National Bureau of Statistics, State Administration of Foreign Exchange

It can be seen from Figure 1 that China's current account balance remains in surplus on the whole and shows a trend of growth first and then decline, which can be divided into the following three stages. The first stage is from 2001 to 2003. During this stage, with China's accession to the WTO in 2001, China's economy entered a stage of rapid growth, with a substantial increase in exports and a rapid expansion of current account surplus. The second stage is from 2004 to 2007. During this period, China's current account surplus 
remained low. During these 12 years, China's current account surplus did not exceed us $\$ 40$ billion, and even recorded a small deficit in 2007.This was closely related to the changes in the international political and economic situation at that time. The third stage is from 2008 to the present. During this stage, with the outbreak of the international financial crisis in 2008 and the slowdown of China's economic growth and the change of its economic development mode after 2013, the current account surplus showed a fluctuating trend of narrowing.

\subsection{Trends of China's Cross-border Balance of Payments in Goods Trade}

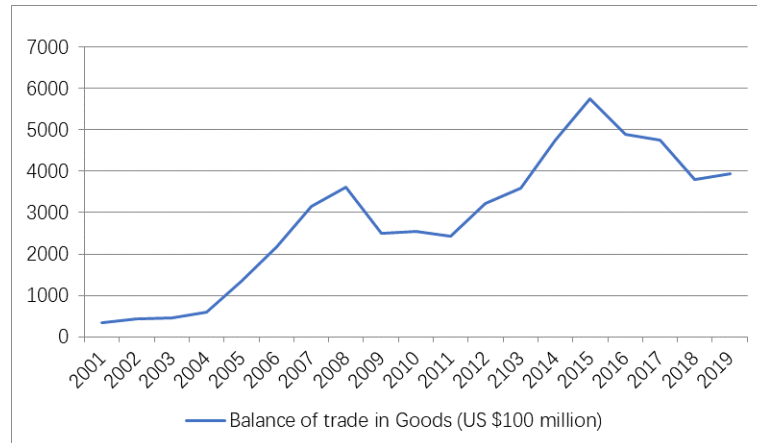

Figure 2: Variation trend of goods trade balance Source: Website of the State Administration of Foreign Exchange

The cross-border balance of goods trade is the main source of the current account balance and has the most significant impact on the change of the current account balance. It can be seen from Figure 2 that from 2001 to 2019, China's cross-border balance of payments in goods trade showed an overall upward trend, with surplus in all years. The surplus peaked in 2015 at $\$ 576.2$ billion. In general, the change of China's cross-border balance of payments in goods trade can be divided into four stages. First, from 2001 to 2004, China's cross-border trade surplus in goods showed a trend of slow expansion, and the cross-border trade surplus was less than us $\$ 100$ billion. Second, from 2004 to 2008, the cross-border trade surplus in goods increased substantially, with an average annual increase of us $\$ 73.275$ billion. At this stage, the huge trade dividend brought by China's accession to WTO makes the cross-border surplus of goods trade expand continuously. Third, from 2009 to 2015, the surplus first showed a rapid decline and then continued to increase. The 2008 international financial crisis had a huge negative impact on China's foreign trade, which narrowed the cross-border surplus of goods trade from 2009 to 2011 . However, with the gradual recovery of the international economy and the introduction of a series of policies in China, the cross-border surplus of goods trade began to expand in 2012 and reached its maximum value in 2015.Fourth, the surplus has declined rapidly since 2015.Since 2015, as the international political and economic situation has changed, China has faced increasing external risks and challenges in its development. The pressure of cross-border capital outflow has increased sharply, and the cross-border trade surplus in goods has begun to shrink rapidly.

2.3 Changes in the Cross-border Balance of Payments in Service Trade

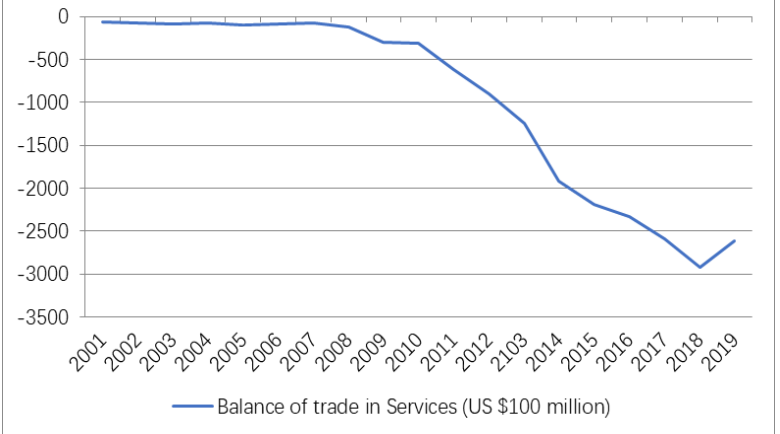

Figure 3: Variation trend of cross-border balance of payments in service trade

Source: Website of the State Administration of Foreign Exchange

Figure 3 describes the trend of China's cross-border balance of payments in service trade from 2001 to 2019.It can be seen that China's cross-border balance of payments in service trade basically showed a trend of stable first and then declining. Development and change can be roughly divided into two stages. First, it was basically stable from 2001 to 2008. During this period, China's cross-border service trade surplus and deficit alternately appeared, and the gap was small. Second, since 2009, China's cross-border service trade deficit has grown rapidly, from 15.3 billion US dollars in 2009 to 261.1 billion US dollars. At this stage, as China's foreign exchanges became more frequent, Chinese citizens' overseas travel, study and visit activities continued to increase, China's foreign exchange payment in service trade increased significantly, and the cross-border deficit in service trade showed a trend of rapid expansion.

\section{The Empirical Analysis of the Factors Affecting the Current Account Balance}

\subsection{Model Construction and Data Sources}

Based on the above analysis of factors affecting the current account balance, it can be seen that economic growth rate, industrial structure, fiscal policy, consumption and other indicators will have a certain degree of impact on the current account balance. Therefore, in combination with the research and theoretical analysis of domestic and foreign scholars on the influencing factors of current account, this paper selects four indicators to conduct an empirical analysis on the influencing factors of China's current account balance.

\subsubsection{Description of variables}

Table 1: Variable indicators and description

\begin{tabular}{|c|c|c|}
\hline & variable & Variable declaration \\
\hline $\begin{array}{l}\text { Explained } \\
\text { variable }\end{array}$ & $\begin{array}{l}\text { Current account } \\
\text { balance (JC) }\end{array}$ & Current account balance \\
\hline \multirow{4}{*}{$\begin{array}{l}\text { Explanatory } \\
\text { variables }\end{array}$} & $\begin{array}{l}\text { Economic Growth } \\
\text { (GDPR) }\end{array}$ & Real GDP growth rate \\
\hline & $\begin{array}{l}\text { Industrial } \\
\text { Structure (CY) }\end{array}$ & $\begin{array}{l}\text { The proportion of added value of } \\
\text { secondary and tertiary industries in } \\
\text { GDP }\end{array}$ \\
\hline & $\begin{array}{l}\text { Financial } \\
\text { Expenditure }(\mathrm{CZ})\end{array}$ & $\begin{array}{l}\text { Fiscal expenditure as a percentage of } \\
\text { GDP }\end{array}$ \\
\hline & $\begin{array}{l}\text { Consumer } \\
\text { Expenditure (XF) }\end{array}$ & $\begin{array}{l}\text { The proportion of total retail sales of } \\
\text { consumer goods in GDP }\end{array}$ \\
\hline
\end{tabular}

Note: Data are from China's statistical Yearbook from 2002 to 2020 and the State Administration of Foreign Exchange. 
In this paper, the current account balance index is selected as the explained variable, economic growth, industrial structure, fiscal expenditure and consumer expenditure are selected as the explanatory variables, and the index interval is set as 2001-2019, reflecting the influencing factors of China's current account changes from the long-term changes. Indicators and data description are shown in Table 1.

\subsubsection{Model construction}

This paper adopts the vector autoregression model (VAR model) proposed by Christopher Sims in 1980. VAR model is used to estimate the dynamic relationship of joint endogenous variables without any prior constraints. VAR model is based on the statistical properties of the data to build the model, each endogenous variable in the system as a function of the lag value of all the endogenous variables in the system to build the model, so as to extend the univariate autoregressive model to the "vector" autoregressive model composed of multivariate time series variables. The general expression of VAR model can be written as:

$Y_{t}=c+A_{1} Y_{t-1}+A_{2} Y_{t-2}+\cdots+A_{p} Y_{t-p}+e_{t}, t=1,2, \ldots, p$ Combined with the research on the impact of economic growth, industrial structure, fiscal expenditure and consumption expenditure on the current account balance, a multivariate Var model including current account balance, economic growth, industrial structure, fiscal expenditure and consumption expenditure is constructed to observe the relationship among the variables. The expression is as follows:

Table 2: ADF test results of each variable

\begin{tabular}{|c|c|c|c|c|c|}
\hline variable & Test form $(c, t, p)$ & ADF value & Information criterion & Prob.* & Conclusion \\
\hline JC & $(\mathrm{c}, \mathrm{t}, 3)$ & 3.1895 & SIC & 0.1212 & Not smooth \\
\hline GDPR & $(\mathrm{c}, \mathrm{t}, 3)$ & 2.7209 & SIC & 0.2411 & Not smooth \\
\hline CY & $(\mathrm{c}, 0,3)$ & 1.8583 & SIC & 0.3427 & Not smooth \\
\hline $\mathbf{X F}$ & $(\mathrm{c}, \mathrm{t}, 3)$ & 2.5054 & SIC & 0.3214 & Not smooth \\
\hline DJC & $(0,0,3)$ & 2.7163 & SIC & 0.0098 & smooth \\
\hline DGDPR & $(0,0,3)$ & 3.8133 & SIC & 0.0437 & smooth \\
\hline DCY & $(0,0,3)$ & 2.3048 & SIC & 0.0252 & smooth \\
\hline DCZ & $(\mathrm{c}, 0,3)$ & 3.8168 & SIC & 0.0115 & smooth \\
\hline DXF & $(0,0,3)$ & 23.9015 & SIC & 0.0001 & smooth \\
\hline
\end{tabular}

Note: $(\mathrm{C}, \mathrm{T}, \mathrm{P})$ represents the constant term, the time trend term and the lag term in the unit root test equation.

The test results show that the p-values of the ADF test statistics corresponding to the original values of all variables are greater than the critical value of 0.05 , so it can be judged that the original values of all variables are unstable series at the significance level of $5 \%$, while the P-values corresponding to the ADF statistics of all first-order difference series are less than the critical value of 0.05 . It can be judged that the first-order difference sequences of variables are all stationary sequences, so all variables are first-order integration sequences, which can be tested and analyzed in the next step.

\subsubsection{Model stability test}

The stability of the model may affect the judgment of the test analysis results. In order to ensure the accuracy and rigor of the empirical analysis, it is necessary to test the stability of the VAR model. In general, all the characteristic roots in the VAR
$\left(\begin{array}{c}J C \\ \mathrm{GDPR} \\ \mathrm{CY} \\ \mathrm{CZ} \\ \mathrm{XF}\end{array}\right)=A_{1}\left(\begin{array}{c}J C_{t-1} \\ G D P R_{t-1} \\ C Y_{t-1} \\ C Z_{t-1} \\ X F_{t-1}\end{array}\right)+\cdots+A_{p}\left(\begin{array}{c}J C_{t-p} \\ G D P R_{t-p} \\ C Y_{t-p} \\ C Z_{t-p} \\ X F_{t-p}\end{array}\right)+\left(\begin{array}{c}\varepsilon_{1 t} \\ \varepsilon_{2 t} \\ \varepsilon_{3 t} \\ \varepsilon_{4 t} \\ \varepsilon_{5 t}\end{array}\right), t=1,2, \ldots, T$

In the above formula, $\mathrm{T}$ is the number of samples, $\mathrm{p}$ is the lag order, is the parameter matrix to be estimated, and is the random disturbance term. $A_{1}, \ldots, A_{P} \varepsilon_{i t}$

\subsubsection{Data sources}

This paper selects the annual data of current account balance, economic growth, industrial structure, fiscal expenditure and consumer expenditure from 2000 to 2019, all data are from China Statistical Yearbook from 2001 to 2019, the website of the State Administration of Foreign Exchange and Wind database.

\subsection{Empirical Analysis}

\subsubsection{Data stationarity test (ADF test)}

Time series is often not stable, if the direct modeling on the basis of stationarity test may appear false regression. In order to avoid such problems, this paper uses ADF value to test whether the data of each variable is stationary. The original hypothesis $\mathrm{H} 0$ : there is unit root; Alternative hypothesis $\mathrm{H} 1$ : There is no unit root. If the ADF value is less than the critical value, we reject the null hypothesis and accept the alternative hypothesis. The test results are shown in Table 2. model are used for judgment. The results in FIG. 2 show that all characteristic roots fall within the unit circle, thus the VAR model is stable.

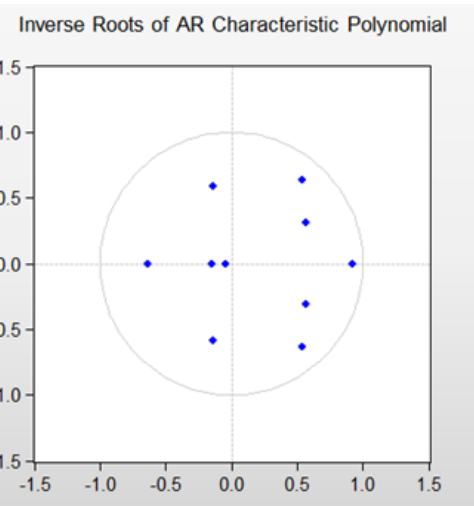

Figure 4: Stability test results of the model

\subsubsection{Cointegration test}


In this paper, Johanse co-integration test is adopted to explore whether there is a long-term co-integration relationship between various variables. The test results are shown in Table 3.

Table 3: Cointegration test results

\begin{tabular}{c|c|c|c|c}
\hline The null hypothesis & $\begin{array}{c}\text { The } \\
\text { eigenvalue }\end{array}$ & $\begin{array}{c}\mathrm{T} \\
\text { statistic }\end{array}$ & $\begin{array}{c}0.05 \text { the critical } \\
\text { value }\end{array}$ & $\begin{array}{c}\mathrm{P} \\
\text { values }\end{array}$ \\
\hline $\begin{array}{c}\text { Zero cointegration } \\
\text { vectors }\end{array}$ & 0.9867 & 115.6457 & 69.8189 & 0.0000 \\
$\begin{array}{c}\text { At most one } \\
\text { cointegration vector }\end{array}$ & 0.6946 & 42.1582 & 47.8561 & 0.1543 \\
\hline $\begin{array}{c}\text { At most 2 } \\
\text { cointegration } \\
\text { vectors }\end{array}$ & 0.5533 & 21.9931 & 29.7971 & 0.2989 \\
\hline $\begin{array}{c}\text { At most three } \\
\text { cointegration } \\
\text { vectors }\end{array}$ & 0.2802 & 8.2926 & 15.4947 & 0.4346 \\
$\begin{array}{c}\text { At most 4 } \\
\text { cointegration } \\
\text { vectors }\end{array}$ & 0.1470 & 2.7032 & 3.8415 & 0.1001 \\
\hline
\end{tabular}

As can be seen from Table 3, at the significant level of 5\%, there is a cointegration relationship between economic growth, industrial structure, fiscal expenditure and consumption expenditure and current account balance in the long run.

\subsubsection{Granger causality test}

On the premise that the time series is stable, Granger causality test of variables can be conducted next. Granger causality test is mainly used to analyze whether a variable can be delayed by other variables. The analysis results are shown in Table 4 .

Table 4: Granger test results

\begin{tabular}{|c|c|c|c|}
\hline The null hypothesis & $\begin{array}{c}\mathrm{F} \\
\text { statistic }\end{array}$ & $\begin{array}{c}\mathrm{P} \\
\text { values }\end{array}$ & Conclusion \\
\hline $\begin{array}{c}\text { GDPR does not Granger Cause } \\
\text { JC }\end{array}$ & 10.6617 & 0.0052 & $\begin{array}{l}\text { Reject the original } \\
\text { hypothesis }\end{array}$ \\
\hline $\begin{array}{c}\text { JC does not Granger Cause } \\
\text { GDPR }\end{array}$ & 0.1989 & 0.6620 & $\begin{array}{l}\text { Accept the } \\
\text { original } \\
\text { assumption }\end{array}$ \\
\hline $\mathrm{CZ}$ does not Granger Cause JC & 5.9918 & 0.0272 & $\begin{array}{l}\text { Reject the original } \\
\text { hypothesis }\end{array}$ \\
\hline JC does not Granger Cause CZ & 1.9198 & 0.1861 & $\begin{array}{c}\text { Accept the } \\
\text { original } \\
\text { assumption }\end{array}$ \\
\hline CY does not Granger Cause JC & 3.9721 & 0.0648 & $\begin{array}{l}\text { Reject the original } \\
\text { hypothesis }\end{array}$ \\
\hline JC does not Granger Cause CY & 0.0045 & 0.9477 & $\begin{array}{l}\text { Accept the } \\
\text { original } \\
\text { assumption }\end{array}$ \\
\hline XF does not Granger Cause JC & 0.1272 & 0.7263 & $\begin{array}{l}\text { Accept the } \\
\text { original } \\
\text { assumption }\end{array}$ \\
\hline JC does not Granger Cause XF & 4.1103 & 0.0608 & $\begin{array}{l}\text { Reject the original } \\
\text { hypothesis }\end{array}$ \\
\hline $\begin{array}{l}\text { CZ does not Granger Cause } \\
\text { GDPR }\end{array}$ & 5.8693 & 0.0285 & $\begin{array}{c}\text { Reject the original } \\
\text { hypothesis }\end{array}$ \\
\hline $\begin{array}{c}\text { GDPR does not Granger Cause } \\
\text { CZ }\end{array}$ & 0.1477 & 0.7061 & $\begin{array}{l}\text { Accept the } \\
\text { original } \\
\text { assumption }\end{array}$ \\
\hline $\begin{array}{l}\text { CY does not Granger Cause } \\
\text { GDPR }\end{array}$ & 6.2163 & 0.0248 & $\begin{array}{l}\text { Reject the original } \\
\text { hypothesis }\end{array}$ \\
\hline $\begin{array}{c}\text { GDPR does not Granger Cause } \\
\text { CY }\end{array}$ & 0.6132 & 0.4458 & $\begin{array}{l}\text { Accept the } \\
\text { original } \\
\text { assumption }\end{array}$ \\
\hline $\begin{array}{c}\text { XF does not Granger Cause } \\
\text { GDPR }\end{array}$ & 0.0731 & 0.7906 & $\begin{array}{l}\text { Accept the } \\
\text { original } \\
\text { assumption }\end{array}$ \\
\hline $\begin{array}{c}\text { GDPR does not Granger Cause } \\
\text { XF }\end{array}$ & 23.1331 & 0.0002 & $\begin{array}{l}\text { Reject the original } \\
\text { hypothesis }\end{array}$ \\
\hline CY does not Granger Cause CZ & 1.2149 & 0.2877 & $\begin{array}{l}\text { Accept the } \\
\text { original }\end{array}$ \\
\hline
\end{tabular}

\begin{tabular}{|c|c|c|c|}
\hline & & & assumption \\
\hline $\mathrm{CZ}$ does not Granger Cause $\mathrm{CY}$ & 0.6913 & 0.4188 & $\begin{array}{l}\text { Accept the } \\
\text { original } \\
\text { assumption }\end{array}$ \\
\hline $\mathrm{XF}$ does not Granger Cause CZ & 0.1305 & 0.7229 & $\begin{array}{l}\text { Accept the } \\
\text { original } \\
\text { assumption }\end{array}$ \\
\hline $\mathrm{CZ}$ does not Granger Cause XF & 101.8691 & 4.E-08 & $\begin{array}{l}\text { Accept the } \\
\text { original } \\
\text { assumption }\end{array}$ \\
\hline XF does not Granger Cause CY & 0.0002 & 0.9891 & $\begin{array}{l}\text { Accept the } \\
\text { original } \\
\text { assumption }\end{array}$ \\
\hline CY does not Granger Cause XF & 44.9093 & 7.E-06 & $\begin{array}{l}\text { Accept the } \\
\text { original } \\
\text { assumption }\end{array}$ \\
\hline
\end{tabular}

The results of granger causality test in Table 4 show that there is a one-way causality between current account balance and economic growth, and a one-way causality between fiscal expenditure and current account balance There is one-way causality between industrial structure and current account balance, one-way causality between consumption expenditure and current account balance, and one-way causality between fiscal expenditure and economic growth There is a one-way causality between industrial structure and economic growth, and a one-way causality between consumption expenditure and economic growth.

\subsubsection{Impulse response function}

The static relationship between variables in the VAR model is known through the co-integration test above, but the complex dynamic relationship between variables is still unknown. Therefore, the impulse response function is selected to obtain the dynamic relationship between variables. Impulse response function can represent the impact degree of an endogenous variable on the current and future values of other variables in the VAR model. The impulse response function of current account balance (JC) is shown in Figure 5.
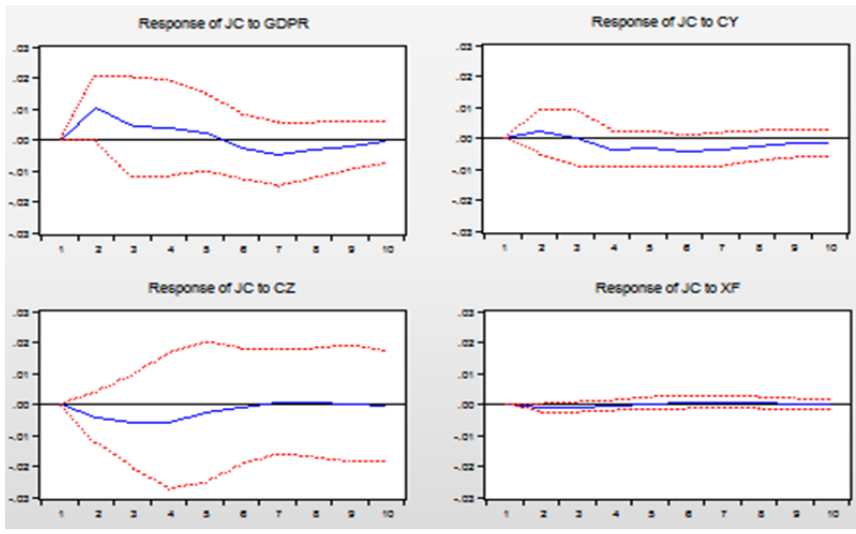

Figure 5: Results of impulse response function

As can be seen from the impulse response function in Figure 5, when the current account balance is given an impact of economic growth, there will be an obvious positive impact in the first five periods, which reaches the maximum in the second period, then turns into a negative impact, and finally gradually tends to be stable. When the current account balance is impacted by the industrial structure, there will be a positive effect in the first three periods, then it will turn into a negative effect, and finally it will gradually stabilize. When the current account balance is given a fiscal expenditure impact, there 
will be a significant negative impact in the first five periods, and then gradually stabilize; When given a consumer-spending hit to the current-account balance, there is no discernable effect. The above pulse results show that the current account balance can be effectively promoted to fluctuate within the target area through the promotion of economic growth, adjustment of industrial structure and improvement of fiscal expenditure.

\section{Conclusions and Suggestions}

\subsection{Conclusions}

Based on VAR model, this paper selected the annual data from 2001 to 2019, based on the economic growth, industrial structure, the fiscal expenditure and consumer spending index variables between the test analysis, analysis of the conclusions are as follows: first, China's current account balance and economic growth, industrial structure, the fiscal expenditure and consumer spending in the long-term stable relationship; Secondly, the four variables of economic growth, industrial structure, fiscal expenditure and consumption expenditure are granger causes of the change of current account balance.

\subsection{Suggestions}

(1) Adjust the target range for current account balance

The empirical results show that the industrial structure can have a certain impact on the current account balance. Since the industrial structure policy is relatively fixed, the target range of the current account balance can be adjusted to some extent according to the annual consumption expenditure policy, fiscal policy and economic growth target.

(2) Establish a current account management system suitable for both domestic and international circulation

Under the development pattern of double circulation at home and abroad, China needs to implement more flexible trade policies and foreign exchange management policies in order to better participate in the economic globalization. At present, China's current account on the basis of full convertibility, the total amount and amount of current account income and expenditure with real transaction background are no longer controlled, and more attention is paid to micro supervision. In this context, it is necessary to adapt to the domestic and foreign double circulation current account management system.

(3) Improve the ability of consumption to adjust to fluctuations in the current account balance

Improve China's income distribution policy and promote the promotion of consumption policy, adjust the proportion of household income distribution between consumption and savings, encourage residents to consume, play the role of consumption in adjusting the current account balance, so as to ensure that the current account balance is stable within the target range.

\section{Acknowledgments}

Foundation Projects: National Natural Science Foundation of China (project number: 71763025); Rural Revitalization Research (project number: Zfyjy201902010); Subject Construction Program of Everest of Tibet University (zf21003004); 2021, Wuhan University of Technology"Tibet Economic and Social Development and scientific research on the plateau to build Innovation Fund" (1zt2021005).

\section{References}

[1] Li G G. Comparative analysis of Sino-US current account from 2005 to 2013[J]. China Market, 2016(24): 222-224.

[2] Teng Yankai. Analysis of current account imbalance in China's international trade $[\mathrm{J}]$. Financial Economics (Theoretical Edition), 2017(4): 5-9.

[3] Dong Dezhi, Jin Jiaqi [J]. Financial Market Research, 2018 (4): 128-136.

[4] Wang Zeyu, Yin Jianling, Zhang Lixiang. Journal of Capital University of Economics and Business, 2019(2) :22-29.

[5] Lu Yue, Lou Chengrong, Du Yingxin et al. Analysis on the impact of trade frictions based on Sino-US tariff lists [J]. Financial Research,2019(2):59-72.

[6] Caballero R J, Farhi E, Gourinchas P. An Equilibrium Model of Global Imbalances and Low Interest Rates[R] Department of Economics Working Paper No.06-02, 2006.

[7] Gruber J W, Kamin S B. Explaining the global pattern of current account imbalances[J]. Journal of International Money and Finance, 2007, 26 (4): 500-522.

[8] ITO H. The U.S. Current account and its implications [J]. Journal of Asian Economics,2009,20(3):294-313.

[9] Zhang Yu, Li Guihua. The impact of fiscal expansion on current account: A comparative analysis based on Chinese and American data [J]. Times Finance, 2018(6):50-53.

[10] Liang Limin. [J]Financial Theory \& Practice, 2017(12): 65-66.

[11] air. The source of China's Trade surplus and its Balance Method [N]. Wen Wei Po, 2014-03-03

[12] Hou Junqiang, Shen Bing, Zhang Yang. He Nina economic growth model on the impact of current account balance changes and countermeasures [J]. Western Finance, 2019(5): 20-26+33.

\section{Author Profile}

Yanhong Gong (1984- ), female, from Lüliang, Shanxi Province, post-doctoral fellow, associate professor and supervisor of master's degree, School of Finance and economics, Southwestern University of Finance and Economics University of Tibet, majoring in financial theory and policy

Feng Xu (1998- ), corresponding author, female, graduate student, University of Tibet, Huaian, Jiangsu 